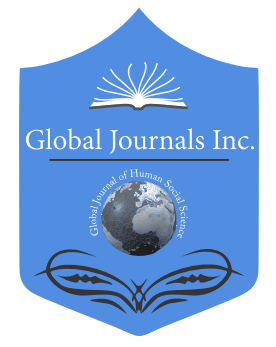

GLOBAL JOURNAL OF HUMAN-SOCIAL SCIENCE: B

GEOGRAPHY, GEO-SCIENCES, ENVIRONMENTAL SCIENCE \& DISASTER MANAGEMENT

Volume 19 Issue 1 Version 1.0 Year 2019

Type: Double Blind Peer Reviewed International Research Journal

Publisher: Global Journals

Online ISSN: 2249-460X \& Print ISSN: 0975-587X

\title{
A Territory-Oriented Approach to Operationilize Sustainable Management
}

By Ana L. burgos \& Alejandro Velázquez

Universidad Nacional Autónoma de México

Abstract- Sustainable science ultimately seeks to minimize the negative impact of human activities on nature, however its role is regarded as limited, chiefly because it lacks a robust spatial framework to join ecological and social processes. Space, from a territorial perspective, is the result of historical interactions between socio-economic forces governing access to natural resources. This paper provides a territorialoriented approach to improve land use policyfrom a spatially explicit perspective. We develop a novel approach, namely 'Territorial Configuration' implying the dissection of the geographic continuum into territorial conglomerates. These are delimited by a range of meaningfully socio-histori calliaisonen compassing a clear understanding of how space is controlled by space holders trigging proximal and underlying governing processes. We discuss how the territorial configuration facilitates overcoming pending issues inland use policy, such as, ecological and geographical articulation, legitimate decisionmaking process, and increase of certainty on the subject of management among others.

Keywords: environmental management, sustainable science, territory, geographic continuum, biodiversity conservation, watershed management.

GJHSS-B Classification: FOR Code: 059999p

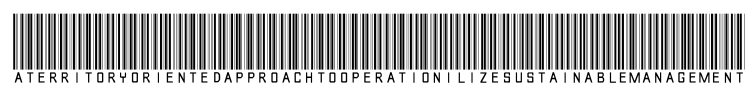

Strictly as per the compliance and regulations of:

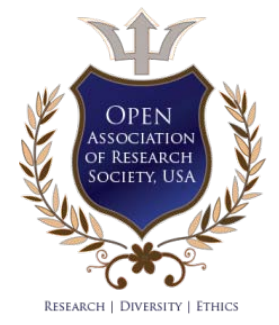

(C) 2019. Ana L. burgos \& Alejandro Velázquez. This is a research/review paper, distributed under the terms of the Creative Commons Attribution-Noncommercial 3.0 Unported License http://creativecommons.org/licenses/by-nc/3.0/), permitting all noncommercial use, distribution, and reproduction in any medium, provided the original work is properly cited. 


\title{
A Territory-Oriented Approach to Operationilize Sustainable Management
}

\author{
Ana L. Burgos ${ }^{\alpha} \&$ Alejandro Velázquez ${ }^{\sigma}$
}

\begin{abstract}
Sustainable science ultimately seeks to minimize the negative impact of human activities on nature, however its role is regarded as limited, chiefly because it lacks a robust spatial framework to join ecological and social processes. Space, from a territorial perspective, is the result of historical interactions between socio-economic forces governing access to natural resources. This paper provides a territory-oriented approach to improve land use policy from a spatially explicit perspective. We develop a novel approach, namely 'Territorial Configuration' implying the dissection of the geographic continuum into territorial conglomerates. These are delimited by a range of meaningfully socio-historical liason encompassing a clear understanding of how space is controlled by space holders trigging proximal and underlying governing processes. We discuss how the territorial configuration facilitates overcoming pending issues in land use policy, such as ecological and geographical articulation, legitimate decision-making process, and increase of certainty on the subject of management among others.
\end{abstract}

Highlights: The geographic continuum dissected by territories gives meaningfully socio-historical basis.

The territorial configuration approach bridges holistically social and ecological approaches.

to sound land use policy.

The territory-oriented approach helps moving forward Keywords: environmental management, sustainable science, territory, geographic continuum, biodiversity conservation, watershed management.

\section{InTRODUCTION}

nvironmental Management (EM) emerged in the 1990s in the light of current man-made pressures on the natural system. It focuses on documenting the relationship between natural resources and human activities and assessing derived proximal and underlying effects on the environment, eventually minimizing the negative impact of human activities. In the last decade, EM has evolved as part of the emerging fields known as Sustainability Science and Transdisciplinary Research. These fields focus on coupled human-environmental systems, science-society links and knowledge systems (Komiyama and Takeuchi 2006; Miller et al. 2014). It is therefore expected that EM be reframed in order to fulfill the needs of Sustainability Science and Transdisciplinary Research (Lang et al. 2012). This reframing is critical to gaining insight from previous experiences

\footnotetext{
Author a $\sigma$ : Centro de Investigaciones en Geografía Ambiental, Universidad Nacional Autónoma de Mexico (UNAM).

e-mail: alex@ciga.unam.mx
}

and eventually in over coming failures. It is undeniable that EM has had a positive impact on a number of topics, namely, biodiversity and forest management and environmental services, among others. Even so, EM has revealed barriers and difficulties when applied to real problems, and its role in sustainable science has been regarded as limited (Conacher 2003; Barrow 2006; Fisher et al. 2012). Coordination and collaboration between stakeholders and institutions have been pinpointed as major weaknesses in terms of achieving effective EM (Margerum and Whitall 2004; Margerum2008; Gregory et al. 2012; Eshrag et al. 2015). The goal of recreating EM as an operational framework and eventually as a bridge to other complementary approaches such as resilience, vulnerability and adaptation (Brand and Jax 2007), confronts a number of challenges: first, a dissected rather than a unified perception of natural resources (soils, water, forests and biodiversity, among others) which occur interacting interdependently at all times in all places (Fish 2011); second, integrative analysis of past, present and future socio-economic underlying driving forces (Ostrom 2008); third, a robust geographic framework to holistically approach the former and latter challenges (Turner et al. 2003); and fourth, recognized mismatches among stakeholders or agencies across multi-level state and non-state governance, involving issues of legitimacy and equity (Margerum 2008; Moss and Newig 2010;Mikulcak et al. 2013). These last two challenges were clearly identified as cornerstones in most ecological studies, and they have remained insufficiently amended.

Space in ecological studies has been approached by dissecting the geographic continuum into vector or raster (pixels) formats (Geoghegan et al. 1998). Other approaches based upon biophysical categories, such as regions, watersheds or aquifers have been used as surrogates for geographic framework (Wu 2006). Neither pixels nor biophysical categories provide a comprehensive understanding of the underlying aspects such as social and governing forces (Liverman et al. 1998). We argue that geographic framework is far more than pure geometric spatial dissection or temporal and functional links and fluxes. Space, from a geographical framework viewpoint, is the result of historical interactions between socio-economic forces governing access to natural resources. Furthermore, space is affected by the presence of 
intertwined feelings connecting people with places by establishing limits through political, economic and cultural processes (Santos 2001; Claval 2002). The aim of depicting the geographic continuum is ultimately to establish boundaries. Boundaries are flexible, fuzzy, porous and dynamic. These boundaries, rather than being limited uniquely by biophysical attributes, are depicted by short and long-term social processes from which territories were then derived. In turn, place-based social processes interaction results in a tied liaison between place and the holder who seeks to control access to all resources (Raffestin and Butler 2012).

Territory deals with space engagement, rules of control and power relationships and ultimately represents the arena for grounded decision-making processes. Territories, however, can also be the following: fuzzy, non-homogeneous, non-consistent and non-contiguous, with disconnected nodes across linking spaces. To our knowledge, EM formulation and practice has remained 'de-territorialized' and little research has been done to provide a territory-oriented approach to link spatially explicit functional relationships between natural resources and socio-economic driving forces.

The aim of this paper is to provide a territoryoriented approach to improve operationalization of Environmental Management from a spatially explicit functional perspective. Specifically, we revisit the roots of the concept of "Territory", hence developing a semantic map to introduce a novel approach, namely "Territorial Configuration". Furthermore, the territorial configuration approach is discussed as a complementary pathway to turn the concept of socioecological systems into effective management actions by providing sustainable science with a robust geographic framework.

\section{il. Environmental Management FRAMEWORK}

Environmental Management (EM) is generally understood as the processes of decision making, planning, administration, implementation and evaluation of human activities--purely driven by social actors such as individuals, community or institutional aggregations-directed toward transforming nature into resources (Barrow 2006). Ideally, EM aims to maximize positive internalities (maximum profit) represented by social groups (stakeholders) and natural resources (object of management) and to minimize negative externalities (minimum environmental costs). The theoretical roots originally established by Patten (1978) refer to "Environmental" as fluxes affecting a system, explicitly related to causes and effects impacting upon the original system state. EM has now come to encompass natural capital conservation, watershed management, payment of ecosystem services and environmental policy programs, among many other issues of sustainable science (Barrow 2006). EM has evolved towards adaptive management and participatory approaches (Kapoor 2001), such that transdisciplinary platforms are strongly recommended (Brand and Karvonen 2007). EM (sensu Margerum 1999) comprises two significantly different connotations, namely, programs geared toward regulating access to resources (so-called "administration" in English, whereas "gestion" and "gestión" in French and Spanish, respectively) and man-made actions to transform nature (ecosystems) into resources (so-called "management" in English and French or "manejo" in Spanish). Because of the two above-mentioned management connotations, two types of flows are identified: top-down and bottom-up. The former is more related to policies, whereas the latter is oriented toward nature transformation.

Lately, social and ecological sciences have been complemented and intermingled with the aim of increasing effectiveness in EM (Young et al. 2006; Díaz et al. 2011). Ecological literature often reports inconsistent spatial concepts, such as bioregions, ecozones, ecodistricts, biophysical units, ecoregions and ecosystems to denote geographic framework (e.g. Margerum 1999; Barrow 2006). Other efforts refer to "Territory" as administrative units (Loiseau et al. 2012) or arbitrary regions such as the Iberian Peninsula (Quintana et al. 2010). Upon thorough review, it became evident that EM has largely neglected the concept of territory. Two well-documented environmental management topics may serve to illustrate the previous statement, namely biodiversity conservation and watershed management.

The establishment of protected areas? has recently emerged as the main environmental policy instrument targeted at preserving ecosystem integrity and biodiversity conservation, as a response to the unprecedented rate of species extinction (Pimm and Raven 2000). Conservation of hot spots and effective management of protected areas have become critical from the global viewpoint. The development of this environmental management policy was clearly illustrated by Naughton et al. (2005), who documented the exponential increase in the number of parks established and the area under protection (in the 1960s there were around 1,000 protected areas, and today there are over 100,000, covering about 20 million $\mathrm{Km}^{2}$ ). The effectiveness of protected areas worldwide, in spite of their clear spatial delimitation (Terborgh 2002), has been largely controversial (Bruner et al. 2001; Rodriguez et al. 2004; Vallino 2014). Design, operation, law enforcement and disengagement of local stakeholders are just a few of the main issues yet to become uniformly effective within protected areas (Cumming et al. 2015). "Making parks work", as literally stated by Terborgh (2002), became critical when studies showed that mega diverse regions harboring most global biodiversity hot spots were the ones most ineffective (Brechin et al. 2003; 
Figueroa and Sanchez-Cordero 2008). In most cases, ineffectiveness has been related to the lack of enrolment of key stakeholders with legal and legitimate jurisdiction and scope for decision making with whom negotiation may take place with the aim of eventually engaging them as core allies (Kaimowitz and Sheil 2007; Velazquez et al. 2009) rather than as the major threat (Terborgh 2002; Redford et al. 2008).

The Watershed Management approach was initially a technical tool defined by hydrological processes with tangible spatial boundaries, and it has recently transformed into a policy framework where watersheds are no longer regarded as biophysical polygons, but rather as governance units (Molle 2009; Cohen and Davidson 2011). It is undeniable, nonetheless, that current progress in conceptual and technical capabilities in watershed management are significant. Uncertainty on the governance issue, however, has emerged as the core challenge. Currently, the most outstanding topics in watershed management are articulation of public policies via coordination across sectorial government agencies (Molle 2009), collaboration and partnerships with non-governments take holders (Margerum and Whitall 2004; Huitema et al. 2009; Benson et al. 2013) and decision-making support systems (Muste et al. 2013). These topics are regarded as stepping stones for promoting watershed governance networks (Castro 2007; Moss and Newig 2010) as well as social learning processes (Pahl-Wostl 2009). The former and the latter are essential underlying conditions for envisaging adaptive capacities and facing uncertainty in water resources and societies that depend on them.

The negligence of a territory-oriented approach in biodiversity conservation and watershed management is even more conspicuous within specific study cases, such as the one in Mexico.

a) Overview of biodiversity conservation and watershed management in Mexico.

Mexico, indisputably regarded as a mega diverse country (Sarukhan et al. 2015), adopted the biodiversity conservation initiative by establishing protected areas. In the 1940s, Mexico set up 39 covering an area of $0.62 \%$ of the national territory, whereas, today, it has established 177, covering $13.04 \%$ of the country's area (www.CONANP.gob.mx). The effectiveness of Mexican protected areas is controversial too. A limited number of protected areas have been somewhat effective in some regions such as the Baja California Peninsula (Rosete et al. 2014), whereas other regions, such as the states of Chiapas, Oaxaca, Guerrero and Michoacan, have been rather ineffective (Figueroa and Sanchez-Cordero 2008). A top-down authoritarian commissioner governs Mexican protected areas, each operated by a director. An advisory committee board (scholars, park administrators and policy makers) supports to a greater or lesser degree from area to area the commissioner-director's decisions. Regional and local stakeholders are mostly overlooked when management policies are designed, and, eventually, these are dictated with the expectation that all concerned will govern themselves accordingly. It has been documented that most outstanding Mexican biodiversity hot spots are not socially empty spaces (Bray and Velázquez 2009; Sarukhan et al. 2015). Under these circumstances, novel territorial conservation strategies based upon genuine engagement of regional and local stake (right) holders with whom agreements and need-based negotiation strategies can be designed, have proved more promising. Protected areas should, therefore, not be primarily targeted at preserving the integrity of pristine functional ecosystem processes or biodiversity sinks, but rather regarded as strategies to reduce inequality and poverty, acting as vehicles of empowerment (Velazquez et al. 2009). As a result, natural resources are regarded by local communities as their natural heritage and therefore fiercely conserved and defended (Brechin et al. 2003; Bray and Velazquez 2009; Herner 2010).

Watershed Management in Mexico started in 1992 under the umbrella of the National Water Law known in Mexico as the "Ley de Aguas Nacionales" (Ortiz-Rendón 1993). Consequently, national territory $\left(1,973,000 \mathrm{~km}^{2}\right)$ was split into 13 administrative hydrological regions. This environmental policy raised expectations as to sound management for contrasting regions -- either by managing hydrological excesses (recurrent floods) or deficits (recurrent droughts) or by providing watershed management as an opportunity for regional development. In turn, basin councils for decision-making were progressively installed, reaching 26 by 2015 (www.CONAGUA.gob.mx). In practice, the National Water Commission, known as the "Comisión Nacional del Agua" enforced a top-down vision in the composition of decision-making structures. Outcomes so far have shown that the capacity of basin councils for institutional coordination and the opportunity for stakeholder collaboration have not fulfilled needs and expectations (e.g. Moreno 2015). These failures remain in spite of manifested political will for tackling national watershed problems (e.g. CONAGUA 2011).

\section{TERRITORY FRAMEWORK}

\section{a) Conceptual Overview}

The concept of territory emerged from the domain of human-political geography (Delaney 2005); and, according to Elden (2010a), it has been used as a surrogate for land, plot, area and landscape, or as a noun to refer to a specific jurisdiction (municipality, state, nation, country). According to Santos (2001), "Territory" is the result of historical interactions between socio-economic forces governing access to natural resources by establishing limits through political, 
economic and cultural processes. In consequence, a "Territory" is under continuous construction and derived by compartmenting the geographical continuum. Owing to the complex socio-economic processes involved in constructing territories, the concept is clearly multipurpose (Paasi 2003a). The concept of Territory is core within the domain of geographical sciences and indisputably comprises polysemic interpretations. In general terms, it refers to the process of engagement or appropriation of a given space by subjects (stakeholders). The concept of territory now refers to an orderly humanized place where nature and culture are melded together through the influence of social institutions in charge of creating and implementing rules targeted at pursuing stakeholders' actions (Raffestin and Butler 2012). Territory is, therefore, a state of power depicting habits, traditions and access to the most critical resource, "the space". To claim there is a Territory, recognizable tangible boundaries, functional or symbolically established borders, rules and levels of governance to enforce them must be present (Elden 2010b; Herner 2010). In this way, engagement or appropriation harbors tangible, functional and cultural territories and denotes a geographic continuum etched by the history of occupation and social meanings (Fig. 1).

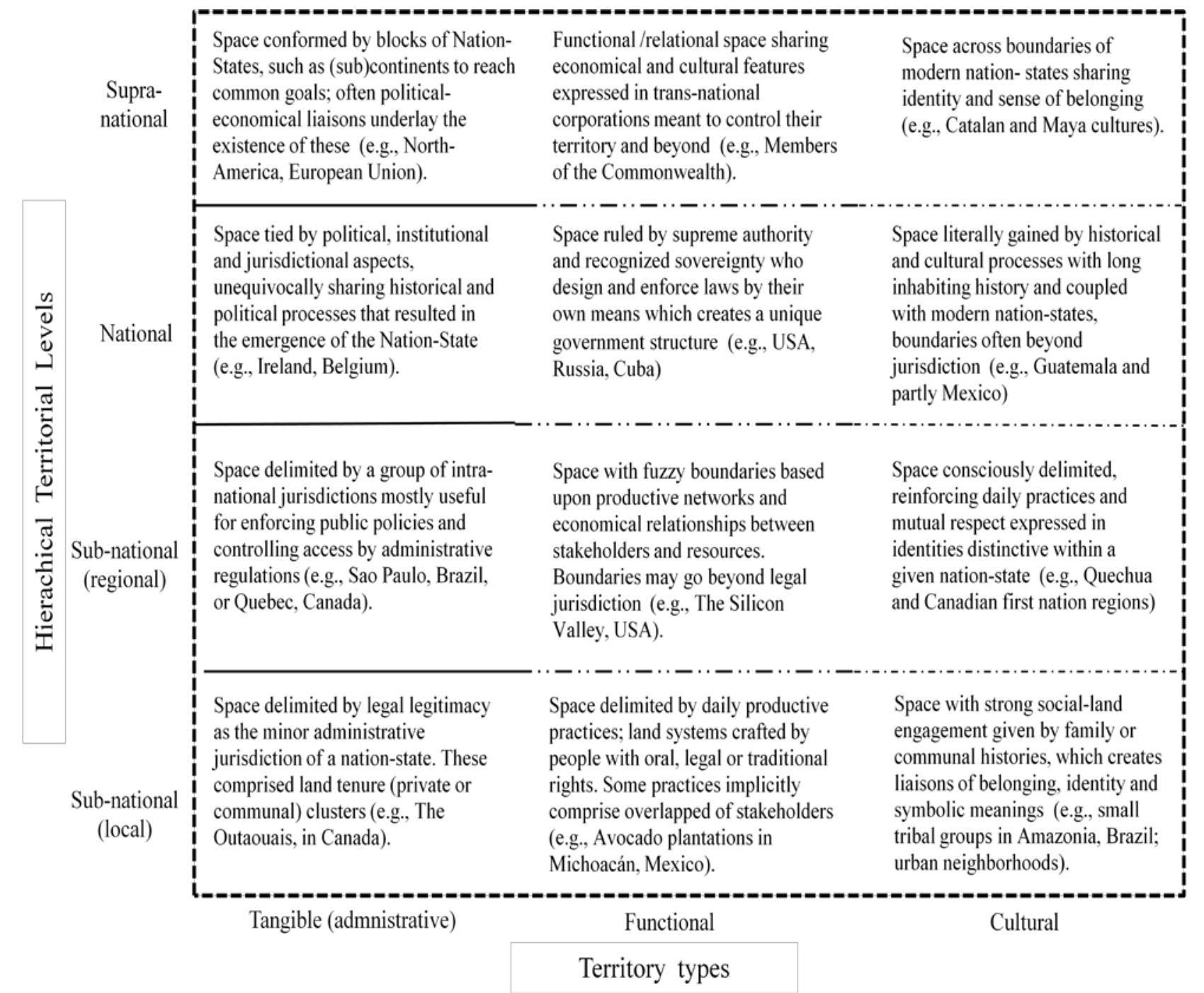

Figure 1: Semantic map describing types and hierarchical levels of territories. These all are spatial entities delineated by boundaries stating degrees of power and jurisdiction by space holders as defined in this contribution.

\section{b) Territory Types}

Tangible (administrative) territory types are spatial expressions delimited by the control of a subject, group or institution with clearly established authority (Fig. 1). The subject ruling tangible territories enforces economic control by controlling use of space and limiting access to natural resources. Tangible (administrative) territories are constructed by pondering, based upon a relative value, the geographic continuum into a recognized spatial arrangement, seeking at compromising externalities among stakeholders and allowing the possibility of being mapped (Newman 2003). These territories are clearly illustrated by spatial entities with specific jurisdiction such as municipalities, 
an established national park or physical boundaries, such as a given watershed, where it is desired to implement a given policy. Tangible (administrative) territories are delimited by clear boundaries, often supported by laws. Sovereignty is therefore crucial and the construction of these territories and its permanence ranges from decades to centuries.

Functional territory types refer to spatial entities with changeable limits characterized by high internal cohesion resulting from practical socio-economic processes derived from natural resource-stakeholder relationships occurring within those given spatial entities (Amin 2004).There are two main types of functional territories: those resulting from long-term endogenous process such as traditional productive systems (e.g., The Chakra [Hammen 1992] and The Chinampa [Parsons 1976]) and those largely driven by exogenous issues, such as global markets, international agreements, and product prices, among others. To illustrate further, consider that a given spatial entity is devoted to soy production. This spatial entity may change drastically if the price of the product drops markedly as a result of global markets. In turn, the former functional territory will adapt to a new situation and, in consequence, the geographic continuum will be re-configured (Peyrony and Denert 2012). Sun-grown coffee, sugar cane, livestock production and mining are clearly other typical examples (Garces-Feliu et al. 2010). Functional territories are delimited by a mosaic of fuzzy boundaries and their permanence ranges from years to decades.

Cultural territory types arise when individual human beings, usually clustered in communities, establish certain engagements or an identity with their spatial entity through symbolic representations. This representation emerges from the inhabited history of the place resulting in cultural milestones (traditions), which indisputably create a unique connection between individuals clustered in communities and their environment. Traditions are built and internalized via socio-cognitive constructions, which govern daily life decisions (Herner 2010). Generally, endogenous issues drive cultural territories. Examples comprise geographic entities sharing food habits, a given language or a specific belief. The geographic continuum split by cultural territories is often intermingled, since symbolic representations may not be shared homogeneously by all members of a given community and, in consequence, they are not universally valid (Newman 1999). Within a given spatial entity, for instance, a community may comprise individuals of the same ethnic group speaking a unique language; said individuals may, nevertheless, not share the same religious beliefs. These symbolic representations, however, comprise the most critical aspects of belonging and identity and therefore the essence of most human beings. Cultural territories are delimited by a degree of fuzzy boundaries and their permanence ranges from centuries to millennia.

\section{c) Hierarchical Territorial Levels}

Hierarchical organization is an important issue in EM, and it has, for decades, been regarded as a cornerstone of sustainable and ecological sciences (Kareiva and Wennergren 1995) as well as of social sciences (Lamont and Molnár 2002). Within the domain of geography, hierarchical territorial levels are the following: local (community-municipality), regional (state-subnational), national and supranational (Fig. 1). Scientific focus on a specific hierarchical level has changed, such that, in the nineteen century, much attention was given to the local and regional; in the twenty century, attention moved towards the national; for the last 30 years, planetary environmental and socioeconomic issues have rekindled interest in territorial expressions at the supranational level (Tuathail and Luke 1994). Hierarchical territorial levels are here described in order of jurisdiction, with national first, followed by regional, local and, last but not least, supranational.

The national territorial level is primarily depicted by political and institutional processes and represents the roots of most nation-states (Antonsich 2010). At a certain point, communities, in spite of their likely cultural differences, gain identity. The notion of a nation hence emerges as a cultural identity of groups, which have historically occupied certain defined spaces. The State governs by means of enforcing laws, which establish control and vigilance over clearly defined spatial limits. These limits designate territorial division where the State exercises sovereignty through legal jurisdictions (Berg and Kuusk 2010). National territories are delimited by indisputably tangible boundaries, and exogenous and endogenous forces rule, such that the exogenous play a key role in the recognition of sovereignty, whereas endogenous forces do so in the exercise of jurisdiction. At this level, urban-rural centers share the ruling role, although this depends on the level of development. It is still mostly centralized governments that take dictatorial decisions.

The regional territorial level (provinces or clusters thereof) is the result of a top-down administrative vision of a nation-state, clearly tangible in their boundaries and aimed at enforcing laws, policies, programs and projects (Baletti 2012). Territories at this level bring to mind the concept of territory as a demographic container (Taylor 1994) or political instrument where the State governs by attending to the local population's needs (Baletti 2012). In these territories, functional issues prevail (Allen and Cochrane 2007), whereas symbolic ones are hardly relevant. To illustrate this, Paasi (2003) differentiated between "identity of a region" and "regional identity". The former aims to enforce a political manipulation of the 
population or market-oriented objectives. The latter is built from the consciousness and feelings of belonging of individuals as a result of a lengthy common history (Jonas 2012). Regional territories are defined by tangible boundaries. If a nation is highly developed, decisions prevail in urban areas; whereas decisions dominated by rural areas prevail if a nation is still developing.

The local territorial (municipal-communal or clusters thereof) level is constructed by a lengthy history of occupation (several generations), where daily life traditional practices have prevailed. At this level, every spatial entity is used, perceived, conceived and lived in by specific stake(right)holders in whom belonging, identity and action converge (Governa and Salone 2004). Definitions of roles are fuzzy, since, for some practices, a stakeholder forms part of one cluster (e.g., livestock producers), yet the same stakeholder may be part of another cluster occupied with another functional activity (e.g., logging). Therefore, at this level, tangible, functional and symbolic territories intermingle, donating life and spirit to the geographic continuum. Yet contested situations are the rule rather than the exception. Local territorial level is not synonymous with indigenous community. Other non-indigenous communities, such as pioneers, immigrants and even emigrants from their place of origin currently expatriate may also qualify as local territory type communities as long as the time of occupation is long enough explicitly to show their engagement and symbolic attachment to the geographic continuum established by traditional practices created by the natural resource-man-made relationship. Urban neighborhoods sharing similar socio-economic classes eventually turn into local territorial identities too. Indigenous communities, nonetheless, often fit as excellent candidates if their traditional practices have not been significantly diminished.

Spatial boundaries of the local territorial level range from tangible to fuzzy owing to the fact that one spatial unit may be devoted to multipurpose functions (Fig. 1). Local level is crucial for implementing actions and is, in consequence, regarded as a motor of development at the municipal level (Jalomo-Aguirre 2009). At this level, space is highly contested because it represents livelihoods and power. Decision-making is also contested, such that open alliances with regional level decision makers are crucial to enforce laws. Because of the contested prevailing framework, this level is rather vulnerable and often unstable in comparison with the regional, national and supranational levels. At this level, rural-urban centers share the ruling role, while the rural ones prevail in most developing countries.

The supranational territorial (global) level emerged through the configuration of clusters of nationstates (the European Union, North American Free Trade
Agreement, MERCOSUR) to address common economic interests, taking into account historical and cultural backgrounds. These are predominantly tangible and gain territorial functionality no longer through the notion of sovereignty, but rather through systems of planning, policies and processes agreed upon by the governments of member nations. Supranational territories are mainly functionally driven and allow the rise of so-called cross-border or trans-border regions, as the case of Western Europe (Zonneveld and Stead 2007; Knipps child and Wiechmann 2012; Peyrony and Denert 2012). These territories have also become relevant spatial entities for attending to environmental problems in order to minimize negative effects as a result of their land-use practices affecting natural resources beyond their borders, sometimes jeopardizing planetary sustainability (Conca 1994). In the symbolic dimension, these supranational territories are palpable in contrasting ways. One of them is the ethno-territorial conflict where national identities are unrecognized through divisions created by the limits of modern states. Conversely, advances in the reconstitution of symbolic territories across state borders have been reached through the recovery of the cohesion based on historic identities as in the case of the Catalan territoriality expressed in Spain, Andorra and France (Prytherch 2010). A number of examples can be seen in the trans-boundary parks in Africa and shared river basins in Mexico and in the USA as well as in many other instances where this supranational territorial level becomes relevant. At this level, urban centers play the ruling role, since centralized governments make most decisions.

\section{iV. Territorial Configuration ApPROACH}

We define territorial configuration (TC) as the array of tangible (administrative), functional and cultural territories that co-exist and overlap across different hierarchical levels. In consequence, the geographic continuum is dissected into territorial conglomerates delimited by a range of meaningful socio-historical boundaries. TC harbors a unique array of stake(right)holders with legal and legitimate rights over the space (hereafter referred to as spaceholders). Accordingly, it is unequivocally place-based dependent (Fig. 2). 


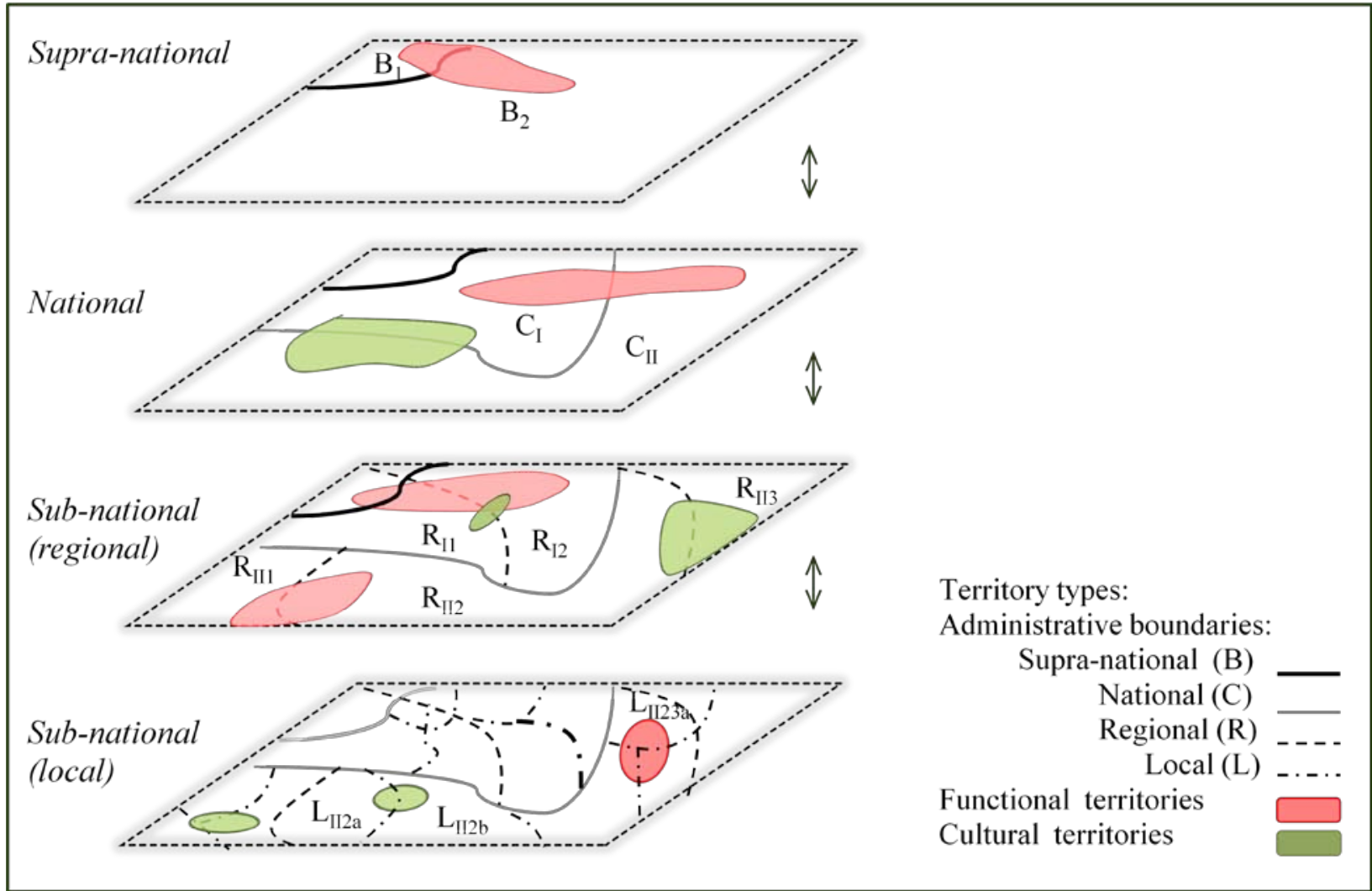

Figure 2: Types and hierarchical levels of territories dissect the geographic continuum forming territorial configuration (TC) conglomerates. The Territorial Configuration approach is meant to provide a common ground where both perspectives may match, namely, jurisdictions, laws and normativity as well as belonging, identities, historical charge, contested spaces and socio-economic functionality. B stands for blocks of countries clustered at supranational boundaries; $\mathrm{C}$ is for country boundaries; $\mathrm{R}$ is for regional boundaries and $\mathrm{L}$ for local boundaries.

From a functional perspective, TC embraces multiple fluxes (matter, energy and information) controlling unstable stages and changing processes throughout territorial conglomerates, thus resulting in non-linear dynamics, such that outcomes are tagged with a high degree of uncertainty. These input-outputs change into internalities or externalities when moving through territorial conglomerates along their path from their departing point toward the endpoint (Fig. 2). Taking into account that fundamental issues in decision-making on environmental management comprise consensus, collaboration and coordination, TC constitutes a benchmark for unified space, function and spaceholders. Three underlying attributes of TC sustain this statement. First, governing spaceholders are identified through their territorial engagement; second, spatially explicit relationships are established to recognize internalities and externalities; third, a negotiation process among spaceholders can be envisaged and strategic pathways leading toward the creation of territorial pacts and agreements may, therefore, be established.

Ambiguity and uncertainty often result from uncoupling actions of the spaceholders, who are distributed across all hierarchical territorial levels.
Because of the spatially explicit character of the TC, ambiguity and uncertainty are diminished because of the need to understand that multiple resources are managed-administrated by multiple stakeholders distributed along a geographic continuum where limits overlap. In response, sound communication is enhanced, and, trust is established easing the implementation of environmental programs. Territorial configuration, in addition, serves to identify key social actors from all territory types as well as any hierarchical level. By understanding the arrangement and the pondered role of these key social actors, agreements, pacts, rules and eventually effective EM may be pursued.

We further state that understanding TC implies admitting that no single EM action will be equally effective in all spatial units. The Territorial Configuration approach here described, places the fact that any environmental management action to be implemented will face opposition. The Territorial Configuration approach takes it as implicit that bottom-up and topdown space holders might be brought together in order to design place-based environmental policies, programs and actions. Consequently, tradeoffs and win-win scenarios are feasible as a crucial first step to regulate 
access to spaces based on reciprocity, shifting to a needs-based rather than rights-based negotiation strategy. To summarize, the Territorial Configuration approach provides meaningful grounds for the processes of decision-making on environmental management (Fig. 3).

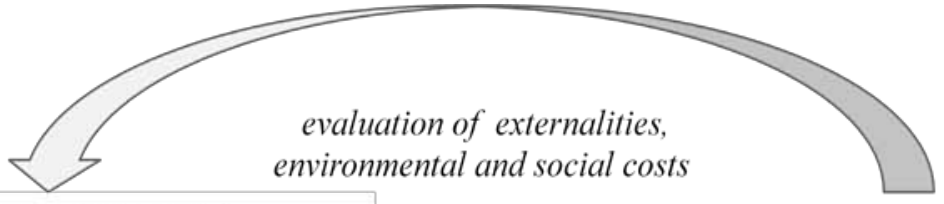

Top-down management

(laws, environmental policies and programs to regulate access to resources)

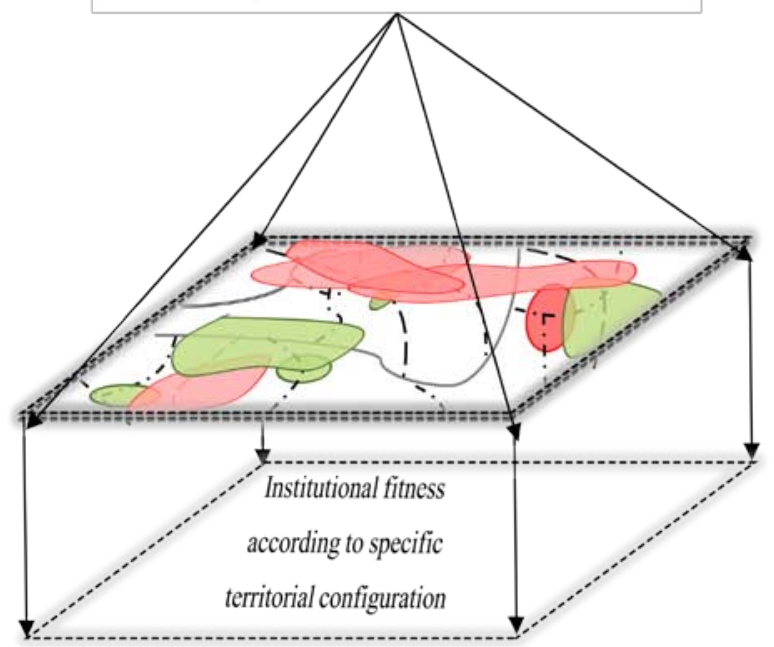

Integrated multi-territorial environmental assessment
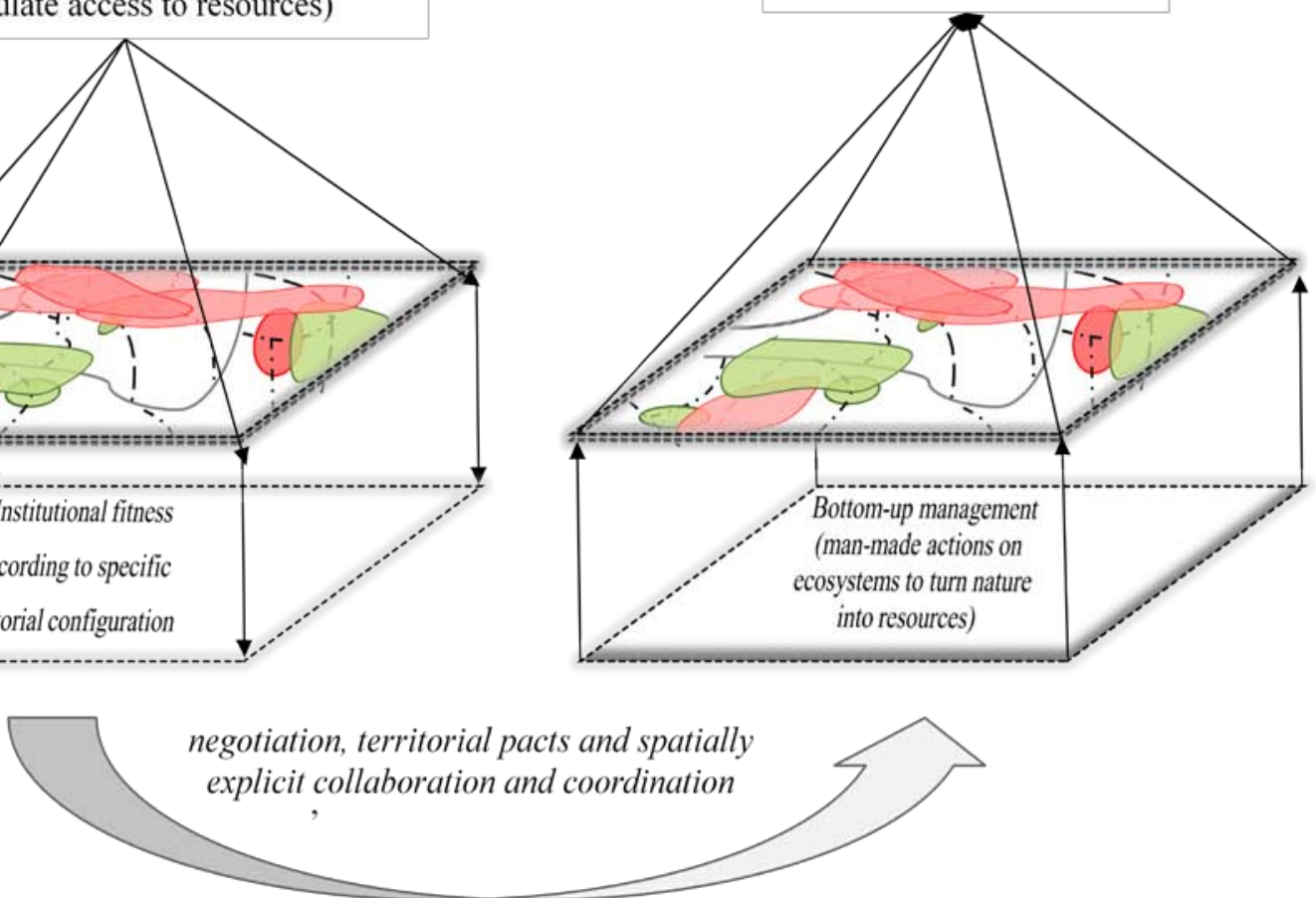

Figure 3: Schematic representation of the virtuous cycle comprised within the Territorial Configuration approach.

Here we portray the cyclical relationship between top-down and bottom-up approaches often unsuitable among institutional organizations, space holders and places. TC conglomerates are crucial for governing national and supranational levels designing policies to regulate access to natural resources (topdown vision). Complementary, bottom-up EM initiatives also adapt their management to their TC. The probability of merging environmental policies with management actions increases because both approaches share the same ground. In addition, because of the place-based institutional framework, pacts, compromises and agreements needed to trigger management actions at regional and local hierarchical territorial levels are feasible too. Environmental actions, even if these are articulated through top-down and bottom-up approaches, trigger positive and negative internalities and externalities. Governing national and supranational levels are able to assess the impact and eventually reorient EM toward sound environmental programs. This dialectical relationship needs to be adapted on an ongoing basis, since TC is invariably changing.

\section{Discussion}

Mexican environmental policy has largely neglected the concept of territory, and overemphasis has been placed on concepts such as ecosystems and, recently, socio-ecological systems (Sarukhán et al. 2015). Environmental management policies targeted at watersheds (Burgos and Bocco 2015) and biodiversity conservation (Bray et al. 2005) are primarily designed following a top-down approach, disregarding TC conglomerates. Despite of all these examples, successful medium- and long-term operation has yet to be ascertained. Disarticulated sector-oriented policies increase uncertainty and diminish trust, such that weaknesses and failures are mainly found in the implementation, monitoring and adaptation phases at regional and local levels (Figueroa and Sánchez Cordero 2008, Velazquez et al. 2009). Most regional and locally driven environmental management programs lead to unsustainable actions, since political will (meaning economic and technical support) is not likely to accommodate initiatives originating with local 
governments, even where legitimate decisions underlay (e.g. peasant reserves). Disruption of the dialectical relationship between top-down and bottom-up processes increases the number and intensity of conflicts among and across territorial conglomerates. In sum, Mexican environmental management initiatives have lacked the dialectical relationship provided by the Territorial Configuration approach.

For a number of decades, the space concept in applied ecological sciences has remained a sticking point (Kareiva and Wennergren 1995) and has often been regarded as a socially empty unit. The revisited concept of territory portrayed here in a semantic map provides an overview of the multipurpose understanding of space. It is argued that territory is a continuous process of spatial construction, permitting socioecological systems to be better understood and eventually effectively managed by regarding the underlying Territorial Configuration. Various authors (e.g., Pahl-Wostl 2009; Moss and Newig 2010) hold that the Territorial Configuration approach may serve as a robust starting point from which to operationalize Environmental Management (Table 1). As previously explained, territorial configuration encompasses a clear notion of space, spaceholders and tangible and cultural proximal and multi-level governing processes (Mikulcak et al. 2013). Understanding this underlying complexity, negotiations, pacts, agreements and reciprocal collaboration are feasible. The Territorial Configuration approach implies reviewing the structure and composition of stakeholders involved in decisionmaking processes. Rather than sector-oriented stakeholders, this approach empowers genuine and legitimate spaceholders to be enlisted so that one common environment a lissue engages neighborhood, contagion and vicinity principles. This engagement leads to pathways toward facilitating governance as a critical component so far over looked in most literature related to Environmental Management (Newig and Fritsh 2008).To illustrate this further, ethnic, political (power), economic and religion-driven cultural features have triggered some of the worst human environmental transformations with global implications. These are the reasons why understanding territorial configuration of space is crucial in finding reconciliatory paths forspaceholders to follow in order to construct new territories from which innovative man-made actions may maximize environmental internalities and minimize externalities (Larson 2010). At this stage, governance and co-operation are likely to be included as a critical route to enforcing rules for a common purpose (Lockwood 2010).

Robust construction between the Territorial Configuration approach and Environmental Management force us to recall that, according to Aguilar (2009), public policy comprises four compulsory and sequential steps, namely, identification of the target, design, implementation and monitoring-adaptation. In addition, Margerum (2008) has pinpointed that frequent atomization and mismatches between sector-oriented policy formulations at high organizational levels remain the major challenge in Environmental Management. Along this line, the Territorial Configuration Approach provides the driving force and basis for environmental policy makers from different sectors to articulate programs and actions. Policy makers should be geared toward common targets according to specific territorial capabilities. Territorial capabilities imply identification of spaceholders who, ideally, should participate actively in all four steps of the public policy cycle. Design of shared programs and actions to be implemented with regard to specific spatial conditions reduce uncertainty and increase trust among spaceholders (Odom et al. 2015). In consequence, the ability to trigger negotiations and pacts in addition to medium- and long-term agreements based upon mutual benefits is developed (Fisher et al. 2012). On the whole, the Territorial Configuration approach may drive Environmental Management into a more effective, concrete and operational framework, making the management of negative externalities more efficient. Eventually, the Territorial Configuration approach should help to avoid policies likely to be antagonistic. These often increase uncertainty and discourage spaceholders (Table 1). 
Table 1: Synthetic comparison among prevailing issues to overcome in sustainable management and improvements reached by following the Territorial Configuration approach.

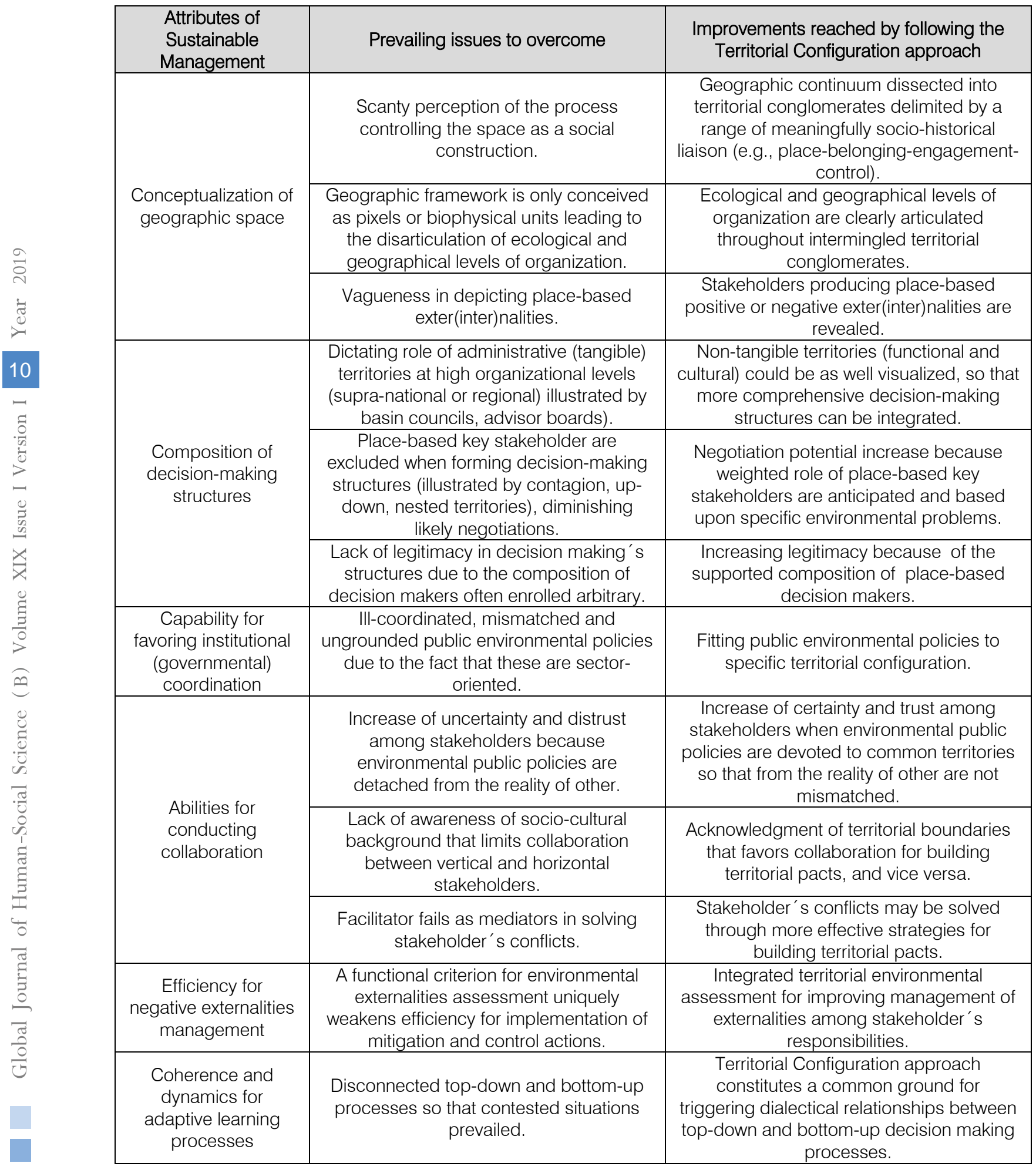


Top-down perspectives dominated by policy makers build the 'reality' around administrative territories at high institutional levels. In contrast, bottom-up perspectives in regional and local spaceholders build their 'reality' around daily life practices derived from tangible, functional and cultural territory types carved outby tacit-empirical knowledge. This mismatch is known as "levels of reality" within the transdisciplinary approach (Nicolescu 2010). The Territorial Configuration approach provided here is meant to serve as common ground where all perspectives can match, namely, jurisdictions, laws and normativity in addition to belonging, identities, historical charge, contested spaces and socio-economic functionality. Contrasting levels of reality ought to be brought together and this approach may serve to do so. This bridging effect refers to literally "the logic of the included middle" described within the transdisciplinary approach by Nicolescu (2010). The Territory Configuration approach may be considered as a surrogate of the included middle because it contains the logic of administrative boundaries in the form of other territorial boundaries linked to different perceptions. Although contrasting perspectives will remain, the building of a shared vision on environmental issues is likely as a consequence of re-connecting the dialectic relationship between topdown and bottom-up perspectives (Table 1 and Fig. 3). This has been identified as the core of the multi-level governance framework (Moss and Newig 2010), governance networks (Newig and Fritsh 2008;Netwig et al. 2010) and knowledge systems, leading to flexible adaptive capacity and triple-loop learning processes (Cash et al. 2003; Fazey et al. 2007; Pahl-Wostl 2009).

\section{Conclusion}

We state that the Territorial Configuration approach provides a sound geographic framework for linking a holistic perception of natural resources as well as past and present socio-economic underlying forces. this approach furthers, serves to resolve the misfit across multi-level state and non-state governance actors. The review on Environmental Management and Territory concepts reveals that territorial configuration of space permits an understanding of the complexity behind Environmental Management occurring along the geographic continuum. Emphasis was given to considering reciprocal connections and dialectical relationships, which determine the continuous construction of emerging territories. In order to reduce the conceptual mismatch between ecological concepts and Environmental Management actions, we suggest a Territorial Configuration approach as a critical pathway.

The outreach of the territory-oriented approach to operationalize Environmental Management in moving forward sustainable science has yet to be ascertained (Miller et al. 2014). Other conceptual approaches so far de-territorialized, such as socio-economic systems, governance and resilience fostering sustainable transitions may also be enriched (Folke et al. 2011; Fabinyi et al. 2014; Norström et al. 2014). It is, therefore, concluded that neither ecosystem nor socio-ecologicalsystem concepts have encompassed a robust platform around which key spaceholders can unite. It is certain, however, that these previous approaches lacked a sound geographic perspective and therefore practical implementation is becoming a burden that needed to be transformed into an opportunity.

\section{ACKNOWLEDGMENTS}

F. Fernández C. and M. McCall provided enriching conceptual comments. Financial support came from project DGAPA-UNAM IN251238. The English was improved by James Fouzie.

\section{References RéférenCes ReFerencias}

1. Aguilar, L. F., 2009. Framework for the analysis of public policies. In Public policy and democracy in Latin America: from the analysis to the implementation, coord. F. Mariñez and V. Graza, 122.EGAP-CERALE-Porrúa, México (in Spanish).

2. Allen, J., and A. Cochrane. 2007. Beyond territorial fix: regional assemblages, politics and power. Regional Studies 41: 161-1175.

3. Amin, A., 2004. Regions unbound: towards a new politics of place. Geografiska Annaler B 86: 33-44.

4. Antonsich, M., 2010. Rethinking territory. Progress in Human Geography 34: 799-817.

5. Baletti, B 2012 Ordenamento Territorial: neodevelopmentalism and the struggle for territory in the lower Brazilian Amazon. Journal of Peasant Studies 39: 573-598.

6. Barrow, C. J., 2006. Environmental Management for Sustainable Development. Routledge, London and New York.

7. Benson, D., A. Jordan, H. Cook, and Smith L., 2013. Collaborative environmental governance: are watershed partnerships swimming or are they sinking? Land Use Policy 30:748-757.

8. Brand, F. S., and Jax K., 2007. Focusing the meaning (s) of resilience: resilience as a descriptive concept and a boundary object. Ecology and Society 12: 23.

9. Brand, R., and Karvonen A., 2007. The ecosystem of expertise: complementary knowledges for sustainable development. Sustainability: Science, Practice and Policy 3: 21-31.

10. Bray, D. B., and Velázquez A., 2009. From Displacement-Based Conservation to Place-Based Conservation. The Case of Community Forest Management. Conservation and Society 7: 11-14. 
11. Bray, D. B., A. Velázquez, J. F. Mas, and Durán E., 2005. Mexico's Community Forests. Conservation in Practice 6: 46-47.

12. Brechin, S. R., C. L. Fortwangler, P. R. Wilshusen, and West P.C., 2003. Contested nature: promoting international biodiversity with social justice in the twenty-first century. Suny Press.

13. Bruner, A. G., R. E. Gullison, R. E. Rice, and Da Fonseca G. A., 2001. Effectiveness of parks in protecting tropical biodiversity. Science 91(5501): 125-128.

14. Burgos, A., and Bocco G., 2015. Watershed as geographic space. In Social Dimensions in Watershed Management. Editors: A. Burgos, G. Bocco, and J. Sosa-Ramirez, 11-29. CIGA-UNAM, Morelia, Mexico. http://www.ciga.unam.mx/public aciones(in Spanish).

15. Cash, D. W., W. C. Clark, F. Alcock, N. M. Dickson, N. Eckley, D. H. Guston, and Mitchell R. B., 2003. Knowledge systems for sustainable development. Proceedings of the National Academy of Sciences 100: 8086-8091.

16. Castro, J. E., 2007. Water governance in the twentieth-first century. Ambiente and Sociedade 10: 97-118.

17. Claval, P., 2002. The cultural approach and geographic notions of space. Boletin de la A.G.E 34: 21-39. http://bibliotecadigital.academia.cl/handle/ 123456789/574(in Spanish).

18. Cohen, A., and Davidson S., 2011. The watershed approach: Challenges, antecedents, and the transition from technical tool to governance unit. Water Alternatives 4: 1-14.

19. Conacher, A. J., 2003. Resources and Environmental Management. Some fundamental concepts and definitions. In Perspectives in Resources Management in Developing Countries (Vol.1), ed. B. Thakur, 49-60.Concept Publishing Company, New Delhi.

20. CONAGUA. 2011. Water Agenda 2030. Secretaria de Medio Ambiente, Recursos Naturales y Pesca (SEMARNAT), Mexico (in Spanish). http://www. conagua.gob.mx/CONAGUA07/Temas/AgendadelA gua2030.pdf

21. Conca, K. 1994. Rethinking the ecology-sovereignty debate. Millenium. Journal of International Studies 23: 701-711.

22. Cumming, G, C., R. Allen, N. C. Ban, D. Biggs, H. C. Biggs, D. H. Cumming, A. De Vos, G. Epstein, M. Etienne, K. Maciejewski, R. Mathevet, C. Moore, M. Nenadovic, and Schoon M., 2015. Understanding protected area resilience: a multi-scale, socialecological approach. Ecological Applications 25:299-3.

23. Delaney, D., 2005. Territory: a short introduction. Blackwell Publishing, Carlton, Australia.
24. Díaz, S., F. Quétier, D. M. Cáceres, S. F. Trainor, N. Pérez-Harguindeguy, M. S. Bret-Harte and Poorter L., 2011. Linking functional diversity and social actor strategies in a framework for interdisciplinary analysis of nature's benefits to society. Proceedings of the National Academy of Sciences 108(3): 895-902.

25. Elden, S 2010a. Land, terrain, territory. Progress in Human Geography 34: 799-817.

26. Elden, S., 2010b. Thinking territory historically. Geopolitics 15: 757-761.

27. Eshragh, F., M. Pooyandeh, and Marceau D. J., 2015. Automated negotiation in environmental resource management: Review and assessment. Journal of Environmental Management 162: 148-157.

28. Fabinyi, M., L. Evans, and Foale S. J., 2014. Socialecological systems, social diversity, and power: insights from anthropology and political ecology. Ecology and Society 19: 28.

29. Fazey, J., J. Fischer, K. Sherren, J. Warren, J. Noss, and Dovers S., 2007. Adaptive capacity and learning to learn as leverage for social-ecological resilience. Frontiers in Ecology and the Environment 5: 375-380.

30. Figueroa, F., and Sánchez-Cordero V., 2008. Effectiveness of natural protected areas to prevent land use and land cover change in Mexico. Biodiversity and Conservation 17: 3223-3240.

31. Fish, R. D., 2011. Environmental decision making and an ecosystems approach some challenges from the perspective of social science. Progress in Physical Geography 35: 671-680.

32. Fischer, J., R. Dyball, I. Fazey, C. Gross, S. Dovers, P. R. Ehrlich, R. J. Brulle, C. Christensen, and Borden R. J., 2012. Human behavior and sustainability. Frontiers in Ecology and the Environment 10: 153-160.

33. Folke, C., Å. Jansson, J. Rockström, P. Olsson, S. R. Carpenter, F. Stuart Chapin III, A. S. Crepin, Daily G., 2011. Reconnecting to the biosphere. Ambio 40: 719-738.

34. Garces-Feliu, E., J. O'Brien, and Cooper M., 2010. From mining location to the continental space. Revista Eure 36: 93-108.

35. Geoghegan, J., L. Pritchard, Y. OgnevaHimmelberger, R. R. Chowdhury, S. Sanderson, and Turner B. L., 1998. Socializing the pixel' and 'pixelizing the social'. In People and pixels: linking remote sensing and social science, 51-69, National Academy of Sciences.

36. Gregory, R., L. Failing, M. Harstone, G. Long, T. McDaniels, and Ohlson D., 2012.Structured decision making: a practical guide to environmental management choices. John Wiley and Sons. 
37. Governa, F., and Salone C., 2004. Territories in action, territories for action: the territorial dimension of Italian local development policies. International Journal of Urban and Regional Research 28: 796-818.

38. Hammen, M. C., 1992. The management of the world: nature and society between the Yukuna of the Colombian Amazon. Tropenbos, Bogotá (in Spanish).

39. Herner, M. T., 2010. The theory of social representations: an approach from Geography. Revista Huellas34: 150-162.

40. Huitema, D., E. Mostert, W. Egas, S. Moellen kamp, C. Pahl-Wostl, and Yalcin R., 2009. Adaptive water governance: assessing the institutional prescriptions of adaptive (co-) management from a governance perspective and defining a research agenda. Ecology and Society 14(1): 26.

41. Jalomo-Aguirre, F., 2009. Local development in metropolitan contexts. Revista Polis 22: 2-12.

42. Jonas, A., 2012. Region and place: regionalism in question. Progress in Human Geography 36: 263-272.

43. Kaimowitz, D., and Sheil D., 2007. Conserving what and for whom? Why conservation should help meet basic human needs in the tropics. Biotropica39(5): 567-574

44. Kapoor, I., 2001. Toward participatory environmental management? Journal of Environmental Management 63: 269-279.

45. Kareiva, P., and Wennergren U., 1995. Connecting landscape patterns to ecosystem and population processes. Nature 373: 299-302.

46. Knippschild, R., and Wiechmann T., 2012. Supraregional partnerships in large cross-border areas-toward a new category of space in Europe? Planning Practice and Research 27: 297-314

47. Komiyama, H., and Takeuchi K., 2006. Sustainability science: building a new discipline. Sustainability Science 1(1): 1-6.

48. Lamont, M., and Molnár V., 2002. The study of boundaries in the social sciences. Annual Review of Sociology: 167-195.

49. Lang, D. J., A. Wiek, M. Bergmann, M. Stauffacher, P. Martens, P. Moll, M. Swilling and Thomas C. J., 2012. Transdisciplinary research in sustainability science: practice, principles, and challenges. Sustainability Science 7(1): 25-43.

50. Larson, A., 2010. Making the 'rules of the game': constituting territory and authority in Nicaragua's indigenous communities. Land Use Policy 27: 1143-1152

51. Liverman, D., E. F. Moran, R. R. Rindfuss, and Stern P. C., 1998. People and pixels: linking remote sensing and social science. National Academy Press, Washington, DC.
52. Lockwood, M., 2010. Good governance for terrestrial protected areas: a framework, principles and performance outcomes. Journal of Environmental Management 91: 754-766.

53. Loiseau, E., G. Junqua, P. Roux, and Bellon-Maurel V., 2012. Environmental assessment of a territory: An overview of existing tools and methods. Journal of Environmental Management 112: 213-225

54. Margerum, R. D., 1999. Integrated Environmental Management: the foundations for successful practice. Environmental Management 24: 151-166

55. Margerum, R. D., 2008. A typology of collaboration efforts in environmental management. Environmental Management 41(4): 487-500.

56. Margerum, R. D., and Whitall D., 2004. The challenges and implications of collaborative management on a river basin scale. Journal of Environmental Planning and Management 47(3): 409-429.

57. Mikulcak, F., J. Newig, A. I. Milcu, T. Hartel, and Fischer J., 2013. Integrating rural development and biodiversity conservation in Central Romania. Environmental Conservation 40(02): 129-137.

58. Miller, T.R., A. Wiek, D. Sarewitz, J. Robinson, L. Olsson, D. Kriebel, and Loorbach D., 2014. The future of sustainability science: a solutions-oriented research agenda. Sustainability Science 9(2): 239246.

59. Molle, F., 2009. River-basin planning and management: The social life of a concept. Geoforum 40(3): 484-494.

60. Moreno, J. L., 2015. Transfer of water and social conflict in the Yaqui River Basin. In Social Dimensions in Watershed Management, Coord. Burgos, A., G. Bocco, and J. Sosa-Ramirez, 227251.CIGA-UNAM, Morelia, Mexico, http://www. ciga.unam.mx/publicaciones (in Spanish).

61. Moss, T., and Newig J., 2010. Multilevel water governance and problems of scale: Setting the stage for a broader debate. Environmental Management 46(1): 1-6.

62. Muste, M. V. , D. A. Bennett, S. Secchi, J. L. Schnoor, A. Kusiak, N. J. Arnold, S. K. Mishra, S.M. ASCE, D. Ding, and Rapolu U., 2012. End-to-end cyber infrastructure for decision-making support in watershed management. Journal of Water Resources Planning and Management 139(5): 565-573.

63. Naughton-Treves, L., M. B. Holland, and Brandon K., 2005. The role of protected areas in conserving biodiversity and sustaining local livelihoods. Annual Review of Environmental Resources 30: 219-252.

64. Newig, J., D. Günther, and Pahl-Wostl C., 2010. Synapses in the network: learning in governance networks in the context of environmental management. Ecology and Society 15(4): 24. 
65. Newig, J., and Fritsh O., $2008 . \quad$ Environmental governance: Participatory, multi-level - and effective? UFZ Diskussionspapiere No. 15/2008.

66. Newman, D., 1999. Real spaces, symbolic spaces: Interrelated notions of territory in the Arab-Israeli conflict. Pages 3 - 34 in P. Diehl, editor. Territorial Dimensions of International Conflict: A Road Map to War. Vanderbilt University Press, Nashville Tenneesse.

67. Newman, D., 2003. Boundaries. Pages 123-137 J. Agnew, K. Mitchell, and G. Toal, editors. A Companion to Political Geography. Blackwell Publishing Ltd.

68. Nicolescu, B 2010 Methodology of transdisciplinarity - levels of reality, logic of the included middle and complexity. Transdisciplinary Journal of Engineering and Science 1(1): 19-38.

69. Norström, A.V., A. Dannenberg, G. McCarney, M. Milkoreit, F. Diekert F, G. Engström, R. Fishman , J. Gars, E. Kyriakopoolou, V. Manoussi, K. Meng , M. Metian, M. Sanctuary 8 , M. Schlüter 1, M. Schoon, L. Schultz and . Sjöstedt M., 2014. Three necessary conditions for establishing effective Sustainable Development Goals in the Anthropocene. Ecology and Society 19(3):8.

70. Odom, O., A. S. Garmestani, C. R. Allen, L. H. Gunderson, J. B. Ruhl, C. A. Arnold, N. A. J. Graham, B. Cosens, D. G. Angeler, B. C. Chaffin and Holling C. S., 2015. Barriers and bridges to the integration of social-ecological resilience and law. Frontiers in Ecology and the Environment 13: 332-337.

71. Ortiz-Rendón, G., 1993. Relevant original concepts of the Law of National Waters. Ingeniería Hidráulica en México enero-abril: 7-13.

72. Ostrom, E., 2008. Institutions and the Environment. Economic Affairs 28(3): 24-31.

73. Paasi, A 2003. Region and place: regional identity in question. Progress in Human Geography 27: 474-485.

74. Pahl-Wostl, C., 2009. A conceptual framework for analyzing adaptive capacity and multi-level learning processes in resource governance regimes. Global Environmental Change 19(3): 354-365.

75. Parsons, J., 1976. The Role of Chinampa Agriculture in the Food Supply of Aztec Tenochtitlan. Pages 242- xx in C. Clell and, editor. Cultural Change and Continuity. Academic Press, New York.

76. Patten, B., 1978. System approach to the concept of environment. Ohio Journal of Science 78: 206222.

77. Peyrony, J., and Denert O., 2012. Planning for cross-border territories: the role played by spatial information. Raumforsch Raumordn 70: 229-240.

78. Prytherch. D., 2010. Vertebrating the region as networked space of flows: learning from the spatial grammar of Catalinst territoriality. Environment and Planning A 42: 1537-1554.

79. Quintana, S.M., B. M. Martin-Ramos, M. C. Martínez and Pastor I. O., 2010. A model for assessing habitat fragmentation caused by new infrastructures in extensive territories-Evaluation of the impact of the Spanish strategic infrastructure and transport plan. Journal of Environmental Management 91(5): 1087-1096.

80. Raffestin, C., and Butler S.A., 2012. Space, territory, and territoriality. Environment and Planning $D$ : Society and Space 30(1): 121-141.

81. Redford, K. H., M. A. Levy, E. W. Sanderson, and de Sherbinin A., 2008. What is the role for conservation organizations in poverty alleviation in the world's wild places? Oryx 42: 516-528.

82. Rodrigues, A. S., S. J. Andelman, M. I. Bakarr, L. Boitani, T. M. Brooks, R. M. Cowling, L. D. C. Fishpool7, G. A. B. da Fonseca, K. J. Gaston, M. Hoffmann1, J. S. Long, P. A. Marquet, J. D. Pilgrim, R. L. Pressey, J. Schipper, W. Sechrest, S. N. Stuart, L. G. Underhill, R. W. Waller, M. E. J. Watts, and Yan X., 2004. Effectiveness of the global protected area network in representing species diversity. Nature 428(6983): 640-643.

83. Rosete, F. A., Velázquez, A., Bocco, G., and Espejel I., 2014. Multi-scale landcover dynamics of semiarid scrubland in Baja California, Mexico. Regional Environmental Change 14(4) 1315-1328.

84. Santos, M., 2000. The nature of space: technique and time, reason and emotion. Editorial Ariel, España (in Spanish).

85. Sarukhán, J., T. Urquiza-Haas, P. Koleff, J.Carabias, R. Dirzo, E. Ezcurra, S. CerdeiraEstrada, and SoberónJ., 2015. Strategic actions to value, conserve, and restore the natural capital of mega diversity countries: the case of Mexico. BioScience 65(2): 164-173.

86. Taylor, P. 1994. The state as container: territoriality in the modern world-system. Progress in Human Geography 18: 151-162.

87. Terborgh, J., 2002. Making parks work: strategies for preserving tropical nature. Island Press.

88. Tuathail, G., and Luke T., 1994. Present at the (dis) integration: deterritorialization and reterritorialization in the New World Order. Annals of the Association of American Geographers 84: 381-398.

89. Turner, B. L., R. E. Kasperson, P. A. Matson, J. J. McCarthy, R. W. Corell, L. Christensen, and Schiller A., 2003. A framework for vulnerability analysis in sustainability science. Proceedings of the National Academy of Sciences 100 (14): 8074-8079.

90. Vallino, E., 2014. The tragedy of the park: an agentbased model of endogenous and exogenous institutions for forest management. Ecology and Society 19(1): 35. 
91. Velázquez, A., E. M. Cué-Bär, A. Larrazábal, N. Sosa, J. L. Villaseñor, M. McCall, and. IbarraManríquez G., 2009. Building participatory landscape-based conservation alternatives: a case study of Michoacán, Mexico. Applied Geography 29: 513-526.

92. Wu, J., 2006. Cross-disciplinarity, landscape ecology, and sustainability science. Landscape Ecology 21:1-4.

93. Young, O. R., F. Berkhout, G. Gallopin, M. A. Janssen, E. Ostrom, and van der Leeuw S., 2006. The globalization of socio-ecological systems: An agenda for scientfic research. Global Environmental Change 16: 304-316.

94. Zonneveld, W., and Stead D., 2007. European territorial co-operation and the concept of urbanrural relationships. Planning, Practice and Research 22: 439-453. 